\title{
PERAN ORANG TUA MENDIDIK KARAKTER ANAK DALAM ISLAM
}

\author{
Heru Mahmudin ${ }^{1}$, Abdul Muhid ${ }^{2}$ \\ Universitas Islam Negeri Sunan Ampel Surabaya \\ Email: aryadamar500@gmail.com¹, abdulmuhid@uinsby.ac.id ${ }^{2}$
}

\begin{abstract}
This study discusses the role of parents in character education for young women according to Islam. This research library research. The main and first character education for children is the family environment. Education in the family is very important and is the main pillar of character building for a child. The family as the smallest social unit is the most important educational environment and is responsible for educating their children. The education provided by parents should provide a basis for children's education regarding the socialization process and their life in society. Good parenting styles will have a good impact on children's development as well as should. The success of character building in children is influenced by the role of parents in educating children. Parents play an important role in forming an intimate and long-lasting interaction system characterized by personal loyalty, love, and affectionate relationships.
\end{abstract}

\section{Keywords: Character education, The role of parent}

\begin{abstract}
Abstrak
Penelitian ini membahas tentang peranan orang tua terhadap pendidikan karakter remaja putri menurut Islam. Penelitian ini merupakan studi pustaka (library research). Pendidikan karakter yang utama dan pertama bagi anak adalah lingkungan keluarga. Pendidikan dalam keluarga sangatlah penting dan merupakan pilar pokok pembangunan karakter seorang anak. Keluarga sebagai satuan unit sosial terkecil merupakan lingkungan pendidikan yang paling utama dan bertanggung jawab mendidik anak-anaknya. Pendidikan yang diberikan orangtua seharusnya memberikan dasar bagi pendidikan anak mengenai proses sosialisasi dan kehidupannya di masyarakat. Pola asuh orangtua yang baik akan membawa dampak baik bagi perkembangan anak demikian juga sebaiknya. Keberhasilan pembentukan karakter pada anak ini salah satunya dipengaruhi oleh peran orang tua dalam mendidik anak. Orangtua memegang peranan penting dalam membentuk sistem interaksi yang intim dan berlangsung lama ditandai oleh loyalitas pribadi, cinta kasih dan hubungan yang penuh kasih sayang.
\end{abstract}

Kata Kunci: Peran orang tua, Pendidikan karakter 


\section{A. Pendahuluan}

Orang tua adalah guru yang paling utama dan yang pertama memberikan pendidikan kepada anaknya dan bertanggung jawab penuh terhadap proses pertumbuhannya. Seorang anak sangatlah membutuhkan bimbingan dari orang tuanya sehingga kelak bisa menjalani kehidupannya sendiri, dalam hal ini terutama bagi remaja putri yang kelak juga akan menjadi ibu yang akan membimbing anaknya kelak, begitu pentingnya peran orang tua yang menjadi sentral pendidikan baik moral maupun emosi anaknya, menjadikan karekter dan kepribadian orang tua juga berpengaruh dalam mendidik anaknya terutama remaja putrinya.

Mewujudkan anak yang baik dan berkualitas adalah tanggung jawab orang tua. Anak merupakan amanah yang diberikan oleh Allah kepadaorang tua yang harus dipertanggung-jawabkan di akhirat. Karena itu orangtua wajib memelihara, membesarkan, merawat, menyantuni, dan mendidik anak-anaknya dengan penuh tanggung jawab dan kasih sayang.

Al-Qur'an digambarkan bahwa anak merupakan penyejuk pandangan mata (qurrata a'yun), sumber kebahagiaan, dan belahan hati manusia di dunia ini.Keberadaan anak dalam suatu keluarga menjadikan keluarga itu terasa hidup, harmonis, dan menyenangkan, sebaliknya ketiadaan anak dalam keluarga menjadikan keluarga tidak berarti apa-apa, karena kehilangan salah satu ruh yang dapat menggerakkan keluarga itu. Di mata seorang bapak, anak akan menjadi penolong, penunjang, pemberi semangat, dan penambah kekuatan. Di mata seorang ibu, anak menjadi harapan hidup, penyejuk jiwa, penghibur hati, kebahagiaan hidup, dan tumpuan di masa depan.

Pendidikan merupakan suatu media yang paling jitu dalam mengembangkan potensi dan membentuk karakter anak baik berupa keterampilan maupun wawasan. Oleh karena itu, pendidikan secara terus-menerus dibangun dan dikembangkan agar dari proses pelak-sanaannya menghasilkan generasi yang diharapkan.

Jurnal Darussalam; Jurnal Pendidikan, Komunikasi dan Pemikiran Hukum Islam Vol. XI, No 2:449-463. April 2020. ISSN: 1978-4767 (Cetak), ISSN: 2549-4171(Online) Terakreditasi Nasional. SK. No.36/E/KPT/2019 
Demikian dengan Indonesia, bangsa kita juga tidak ingin menjadi suatu bangsa yang bodoh dan keterbelakang terutama dalam menghadapi zaman yang terus berkembang di era kecangihan teknologi dan komunikasi. Pendidikan merupakan salah satu hal yang sangat penting untuk anak-anak di Indonesia. Sampai sekarang, masih banyak orang tua yang tidak mempedulikan pendidikan anak-anaknya.

Perkembangan zaman dan kemajuan teknologi menuntut manusia tidak hanya cerdas intelektual atau biasa disebut dengan cerdas IQ (Intelligence Qoutient) namun juga berkarakter. Karakter merupakan kepribadian khusus yang menjadi pendorong dan penggerak, serta yang membedakan dengan individu lain. Untuk membentuk karakter seorang anak, orangtua memerlukan proses yang relatif lama dan terus menerus. Karakter di bentuk melalui pendidikan karakter. Pendidikan karakter yang utama dan pertama bagi anak adalah lingkungan keluarga. Dalam lingkungan keluarga, anak akan mempelajari dasar-dasar perilaku yang penting bagi kehidupannya di masa yang akan datang.

Keluarga sebagai satuan unit sosial terkecil merupakan lingkungan pendidikan yang paling utama dan pertama, dalam arti keluarga merupakan lingkungan yang paling bertanggung jawab mendidik anak-anaknya. Pendidikan yang diberikan orangtua seharusnya memberikan dasar bagi pendidikan, proses sosialisasi dan kehidupannya di masyarakat. Keluarga menjadi kelompok pertama (primary group) tempat meletakan dasar kepribadian di dalam keluarga. Orangtua memegang peranan membentuk sistem interaksi yang intim dan berlangsung lama ditandai oleh loyalitas pribadi, cinta kasih dan hubungan yang penuh kasih sayang. Peran orangtua adalah dengan membenahi mental higeine anak.

Secara umum orang-orang memandang bahwa keluarga merupakan sumber pendidikan moral yang paling utama bagi anak-anak. Orangtua adalah guru pertama mereka dalam pendidikan moral. Mereka jugalah yang memberikan pengaruh paling lama terhadap perkembangan moral anak-anak, ketika disekolah, para guru pengajar akan berubah setiap tahunnya, tetapi di luar sekolah anak-anak tentunya memiliki sedikitnya satu orangtua yang memberikan bimbingan dan mem-besarkan mereka selama bertahun-tahun.

Jurnal Darussalam; Jurnal Pendidikan, Komunikasi dan Pemikiran Hukum Islam Vol. XI, No 2:449-463. April 2020. ISSN: 1978-4767 (Cetak), ISSN: 2549-4171(Online) Terakreditasi Nasional. SK. No.36/E/KPT/2019 
Anak merupakan investasi masa depan bagi orangtua. Setiap orang tua menginginkan kebaikan bagi anaknya, baik di dunia maupun di akhirat. Anak merupakan tanggung jawab utama orang tua. Bagi Anak, keluarga adalah wahana pertama dan utama bagi pendidikan karakter anak. Berhasil mendidik anak-anak dengan baik adalah impian semua orangtua. Setiap orang tua pasti ingin agar anaknya bisa sukses dan bahagia, namun apakah pada kenyataannya semudah itu? Mayoritas orang tua pernah mengalami kesulitan dalam mendidik buah hati tercinta. Dalam hal ini, membatasi pendidikan karakter pada lingkungan keluarga, serta menguraikan mengenai peran orang tua dalam membentuk karakter anak.

\section{B. Landsan Teori}

\section{Pendidikan Karakter}

Ditinjau dari akar katanya, dalam Zaim Elmubarok (2008:102) berasal dari bahasa Latin "Kharakter", "kharassein" dan "kharax" yang memiliki makna "tool for marking", "to engrave" dan "pointed stake". Kemudian pada abad 14 di Perancis kata "character" banyak digunakan kembali sehingga sampai akhirnya masuk dalam bahasa Inggris "character" dan di terjemahkan dalam bahasa Indonesia menjadi “ karakter". Kata "toengrave” bisa diterjemahkan mengukir, melukis, memahatkan, atau menggoreskan (Echols dan Shadily, 1995: 214). Dalam Kamus Bahasa Indonesia kata "karakter"diartikan dengan tabiat, sifat-sifat kejiwaan, akhlak atau budi pekerti yang membedakan seseorang dengan yang lain, dan watak. Karakter juga bisa berarti huruf, angka, ruang, simbul khusus yang dapat dimunculkan pada layar dengan papan ketik (Pusat Bahasa Depdiknas, 2008: 682).

Secara terminologis karakter adalah " $A$ reliable inner disposition to respond tosituations in a morally good way." Selanjutnya Lickona menambahkan, "Character soconceived has three interrelated parts: moral knowing, moral feeling, and moral behavior" (Lickona, 1991:51). Menurut Lickona, karakter mulia (good character) meliputi pengetahuan tentang kebaikan (moral khowing), lalu menimbulkan komitmen (niat) terhadap kebaikan (moral feeling), dan akhirnya benar-benar melakukan kebaikan (moral behavior). Dengan kata lain, Jurnal Darussalam; Jurnal Pendidikan, Komunikasi dan Pemikiran Hukum Islam Vol. XI, No 2:449-463. April 2020. ISSN: 1978-4767 (Cetak), ISSN: 2549-4171(Online) Terakreditasi Nasional. SK. No.36/E/KPT/2019 
karakter mengacu kepada serangkaian pengetahuan (cognitives), sikap (attitudes), dan motivasi (motivations), serta perilaku (behaviors) dan keterampilan (skills).

\section{Peran Orang Tua}

Pengertian peran menurut definisi para ahli menyatakan bahwa peran adalah "aspek dinamis dari kedudukan atau status."Seseorang melaksanakan hak dan kewajiban, berarti telah menjalankan suatu peran." Peranan:"suatu yang jadi bagian atau yang memegang pimpinan yang terutama dalam terjadinya sesuatu hal atau peristiwa" (Ali, 2008:304.)

Jadi,peran merupakan sesuatu yang mengandung hal-hal antara lain, bagian dari tugas utama yang harus dilakukan oleh suatu manajemen, pola prilaku yang diharapkan dapat menyertai suatu status, bagian suatu fungsi sesorang dalam kelompok atau pranata, fungsi yang diharapkan dari seseorang atau menjadi karakteristik yang ada padanya dan fungsi setiap variabel dalam hubungan sebab akibat.

\section{Metode Penelitian}

Penelitian ini merupakan studi pustaka (library research) yaitu penelitian yang bersumber dari bahan-bahan kepustakaan. Oleh karena itu, yang dilakukan adalah eksplorasi terhadap sejumlah data baik itu data primer maupun data sekunder dengan langkah konkret sebagai berikut: membaca serta menelaah secara mendalam data primer seperti buku yang merupakan hasil penelitian, tesis maupun disertasi yang terkait dengan psikologi dan pendidikan Islam. Sementara itu, untuk data sekunder, penulis membaca dan menelaah buku dan jurnal yang relevan dengan penelitian ini,kemudian selanjutnya dianalisis dalamperspektif pendidikan Islam.

\section{Hasil}

\section{Pendidikan Karakter Anak}

Foerster dalam buku Zaim Elmubarok (2008:104), mengungkapkan bahwa karakter merupakan sesuatu yang mengkualifikasi seorang pribadi, artinya 
karakter menjadi identitas yang mengatasi pengalaman kontingen yang selalu berubah. Dari kematangan karakter inilah kualitas seorang pribadi bisa terukur.

Koesoema dalam Hermino (2015), mengemukakan bahwa pendidikan karakter merupakan pendidikan yang dibentuk melalui Pendekatan parsial yang tidak didasari pendekatan pedagogi yang kokoh untuk menanamkan nilai-nilai keutamaan dalam diri anak.

\section{Peran Orang Tua Dalam Mendidik Karakter Anak}

Keluarga merupakan pendidikan yang pertama dalam membentuk kepribadian anak. Cara pola asuh dan kebiasaan yang sering dilakukan akan tercermin pada kepribadian anak itu sendiri. Keluarga atau orang tua memberikan pengalaman kepada anak dalam bidang kehidupan, sehingga anak memiliki informasi yang banyak merupakan alat bagi anak untuk berfikir. Dengan memberikan kesempatan kepada anak untuk mewujudkan ide gagasannya, menghargai ide gagasan tersebut, memuaskan rasa keingin tahuan anak. Pengalaman atau pemberian kesempatan tersebut sudah tentu membutuhkan perhatian orang tua. Dengan demikian orang tua harus memahami sehingga tidak terjadi kesalahan dalam menilai anak (Hariyadi , 2018:268).

Kriteria untuk menjadi orang tua ideal tidak sesederhana yang kita bayangkan, baik mereka yang berlatar pendidikan rendah maupun yang berlatar pendidikan tinggi. Bagi orang tua yang berperan ganda seperti ibu misalnya, tentu saja memiliki keterbatasan waktu dan tenaga untuk memberikan sentuhan fisik dan psikis bagi anak-anaknya sekalipun demikian ibu yang ideal untuk mencapai kriteria ideal, paling tidak, orang tua menunjukan semangat dan upaya untuk berusaha lebih baik dalam memenuhi kebutuhan anaknya di berbagai sisi, baik fisik, fsikis maupun sosial anak. Selain itu komunikasi dalam keluarga perlu dibangun dalam rangka pola pikir anak dan membangun jiwa anak agar sesuai dengan harapan orang tua. Dalam lingkungan keluarga orang tua berperan sebagai institusi pendidikan, artinya tidak cukup dengan komunikasi saja, tetapi di dalamnya terjadi komunikasi dalam bidang keagamaan, sosial, dan perlindungan yang dilakukan orang tua terhadap anak-anaknya. Perawatan orang tua yang penuh kasih sayang merupakan faktor yang kondusif untuk mempersiapkan anak 
menjadi pribadi dalam anggota masyarakat yang sehat (Nursalam \& Muhammad Nawir, 2018: 557).

Adapun peran orang tua baik ibu maupun ayah dalam keluarga dijelaskan sebagai berikut :

1. Peran Ibu

Ibu memegang peran penting dalam mendidik anak-anaknya.Sejak dilahirkan ibulah yang selalu disampingnya, memberi makan, minum mengganti pakaian dan sebagainya.Karena itu anak lebih cinta kepada ibunya dari pada kepada anggota keluarga lainya. Ibu dalam keluaraga merupakan orang yang pertama kali berinteraksi dengan anaknya, ia orang yang pertama kali yang di kenal anaknya. Dari ibunya anak mengenal keamanan lahir batin. Ibu menjaga anaknya agar tetap sehat dan hidup, ia merawat anaknya dengan penuh kasih sayang tanpa mengenal lelah dan berat beban tugasnya. Pengalaman anak dengan ibunya akan sangat terkesan, seumur hidupnya akan terkenang atas perlindungan, pemeliharaan dan dorongan serta kasih sayangnya. Dari seorang ibunya diharapkan ia menghadapi anaknya dengan penuh kasih sayang, sehingga dikatakan bahwa'ibu berperan sebagai lembaga kasih sayang”'.

Ngalim Purwanto mengatakan bahwa sesuai dengan fungsi serta tanggung jawabnya sebagai anggota keluarga, dapat dijelaskan bahwa peran ibu dalam pendidikan anak-anaknya adalah sebagai berikut: Sumber dan pemberian rasa kasih sayang, Pengasuh dan pemelihara, Tempat mencurahkan isi hati, Pengatur dalam kehidupan berumah tangga, Pembimbing hubungan pribadi dan emosional, Pendidik dalam segi-segi emosional.

2. Peran Ayah

Disamping ibu, ayah pun mempunyai peranan yang tidak kalah pentingnya terhadap pembentukan karakter anak.Anak memandang ayahnya sebagai orang yang gagasan, paling berani, paling perkasa.Kegiatan yang dilakukan ayah dalam pekerjaan sangat berpengaruh besar kepada anakanaknya.

Jurnal Darussalam; Jurnal Pendidikan, Komunikasi dan Pemikiran Hukum Islam Vol. XI, No 2:449-463. April 2020. ISSN: 1978-4767 (Cetak), ISSN: 2549-4171(Online) Terakreditasi Nasional. SK. No.36/E/KPT/2019 
Menurut Ngalim Purwanto dikutip oleh Uyoh Sadulloh (2001). peranan ayah dalam pendidikan anak-anaknya adalah: Sumber kekuasan dalam keluarga, Penghubung intern antara keluarga dengan masyarakat atau dunia luar, Pemberi rasa aman bagi seluruh anggota keluarga, Pelindung terhadap ancaman dari luar, Hakim atau yang mengadili jika terjadi perselisihan.

3. Pendidik dalam segi rasional.

Meskipun peranan orang tua terhadap keberhasilan anak di sekolah telah lama dikenal, penyediaan layanan bimbingan dan latihan bagi orang tua di sekolah, perlu tindakan orang tua menjadi guru bagi anak mereka di rumah tergantung pada berbagai keadaan. Jika orang tua mampu menjalin hubungan yang baik dengan anak, menguasai bahan pelajaran dan metode pengajarannya, dan miliki waktu untuk mengajar, ada baiknya orang tua menjadi guru bagi anak mereka di rumah (Mulyon, 2003: 99).

Ada beberapa hal kegiatan yang bisa dilakukan oleh orang tua dalam mendidik anaknya di rumah seperti (Siti Zulaiha, 2018: 61-64): Meminta izin sebelum berpergian, Mengawasi kegiatan anak belajar dirumah, Mengenal atau menolong kesulitan-kesulitan anak dalam belajar dirumah.

\section{E. Pembahasan}

\section{Pendidikan Karakter Anak}

Dari beberapa pengertian di atas dapat dipahami bahwa karakter identik dengan akhlak. Kata akhlak yang berasal dari bahasa Arab akhlaq (yang berarti tabiat, perangai,dan kebiasaan) banyak ditemukan dalam hadis Nabi Saw. Dalam salah satu hadisnyaRasulullah SAW. bersabda, "Sesungguhnya aku diutus hanya untuk menyempurnakan akhlak yang mulia”. (HR. Ahmad).

Karakter atau akhlak merupakan nilai-nilai perilaku manusia yang universal yang meliputiseluruh aktivitas manusia, baik dalam rangka berhubungan dengan Tuhan, dengan dirisendiri, dengan sesama manusia, maupun dengan lingkungan, yang terwujud dalampikiran, sikap, perasaan, perkataan, dan perbuatan berdasarkan norma-norma agama,hukum, tata karma, budaya, dan adat istiadat.

Jurnal Darussalam; Jurnal Pendidikan, Komunikasi dan Pemikiran Hukum Islam Vol. XI, No 2:449-463. April 2020. ISSN: 1978-4767 (Cetak), ISSN: 2549-4171(Online) Terakreditasi Nasional. SK. No.36/E/KPT/2019 
Kata yang setara maknanya dengan akhlak adalah moral dan etika.Kata-kata ini sering disejajarkan dengan budi pekerti, tata susila, tata krama atau sopansantun (Faisal Ismail, 1998:178).secara konseptual kata etika dan moral mempunyaipengertian serupa, yakni sama-sama membicarakan perbuatan dan perilaku manusia ditinjau dari sudut pandang nilai baik dan buruk.

Sementara Zubaedi dalam pinkan (2019) menyatakan bahwa Pendidikan karakter di Indonesia didasarkan pada sembilan pilar nilai-nilai dasar pendidikan karakter. Kesembilan pilar karakter dasar, antara lain:1. cinta kepada Allah dan semesta beserta isinya; 2. tangggung jawab, disiplin, dan mandiri; 3. jujur; 4. hormat dan santun; 5. kasih sayang, peduli, dan kerja sama; 6. percaya diri, kreatif, kerja keras, dan pantang menyerah; 7. keadilan dan kepemimpinan; 8. baik dan rendah hati; 9. toleransi, cinta damai, dan persatuan.

Memiliki anak yang sempurna adalah harapan setiap orangtua. Adapun nilainilai yang terkandung dalam pendidikan karakter adalah sebagai berikut (Anas , 2013:111-112):

1. Religius, sikap dan perilaku yang patuh dalam melaksanakan ajaran agama yang dianutnya.

2. Jujur, perilaku yang didasarkan pada upaya menjadikan dirinya sebagai orang yang selalu dapat dipercaya dalam perkataan, tindakan dan pekerjaan.

3. Toleransi, sikap dan tindakan yang menghargai perbedaan agama, suku, etnis, pendapat, sikap, dan tindakan orang lain yang berbeda dari dirinya.

4. Disiplin, tindakan yang menunjukkan perilaku tertib dan patuh pada berbagai ketentuan dan peraturan.

5. Kerja keras, perilaku yang menunjukkan upaya sungguh-sungguh dalam meng-atasi berbagai hambatan belajar dan tugas, serta menyelesaikan tugas dengan sebaik-baiknya.

6. Kreatif, berpikir dan melakukan sesuatu untuk menghasilkan cara atau hasil baru dari sesuatu yang telah dimiliki.

7. Mandiri, sikap dan perilaku yang tidak mudah bergantung pada orang lain dalam menyelesaikan tugas-tugas.

Jurnal Darussalam; Jurnal Pendidikan, Komunikasi dan Pemikiran Hukum Islam Vol. XI, No 2:449-463. April 2020. ISSN: 1978-4767 (Cetak), ISSN: 2549-4171(Online) Terakreditasi Nasional. SK. No.36/E/KPT/2019 
8. Demokratis, cara berpikir, bersikap, dan bertindak yang menilai sama hak dan kewajiban dirinya dan oranglain.

9. Rasa ingin tahu, sikap dan tindakan yang selalu berupaya untuk mengetahui lebih mendalam dan meluas dari sesuatu yang dipelajarinya, dilihat dan di dengar.

10. Semangat kebangsaan, cara berpikir, bertindak, dan berwawasan yang menempatkan kepentingan bangsa dan Negara diatas kepentingan diri dan kelompoknya.

11. Cinta tanah air, cara berpikir, bersikap, dan berbuat yang menunjukkan kesetiaan, kepedulian, dan penghargaan yang tinggi terhadap bahasa, lingkungan fisik, sosial, budaya, ekonomi, dan politik bangsa.

Dasar pendidikan karakter tersebut diterapkan sejak usia kanak-kanak atau yang biasa disebut oleh ahli psikologi sebagai golden age atau usia emas. Usia 0-8 tahun ibarat fondasi pada sebuah bangunan. Jika fondasi tersebut disusun dengan bahan-bahan yang baik dan teranyam kuat, bangunan setinggi apapun yang ada di atasnya akan berdiri kukuh. Tidak akan terguncang dengan angin. Pada anak usia dini terbukti sangat menentukan kemampuan anak dalam mengembangkan potensinya. Munculnya potensi atau ke-mampuan anak bergantung pada rangsangan yang diberikan orang tua.

\section{Peran Orang Tua Dalam Mendidik Karakter Anak}

Pendidikan dan pemahaman yang diberikan oleh orang tua tentunya harus memiliki kepribadiaan yang unggul disamping memiliki pengetahuan yang cukup baik dari segi pendidikan formal, teknologi, informasi dan yang terpenting pemahaman agama, untuk itu ada beberapa unsur pokok yang harus dipenuhi untuk memaksimalisasikan peran orang tua agar dapat mendidik anak mereka yakni (Arhjayati, 2013: 96-98):

1. Memiliki pengetahuan agama yang baik

Orang tua harus memiliki pengetahuan agama dan memberikan contoh yang baik kepada anaknya, karena ketika orang tua telah memberikan contoh bagaimana menjalankan hidup dengan melandaskan pada ajaran agama akan menimbulkan efek langsung terhadap anak remaja mereka. Pemenuhan akan 
pengetahuan agama menjadi hal yang positif bagi kelangsuangan pertumbuhan moral dan sebagai perisai dari perkembangan zaman yang akan menghindarkan mereka kepada perbuatan yang negatif dan merusak masa depan mereka.

2. Berwawasan luas.

Perkembangan teknologi dan informasi di zaman modern ini merupakan hal yang tidak dapat dibendung karena hal tersebut sudah merupakan kebutuhan yang mendasar bagi semua kalangan, untuk itu menjadi orang tua juga harus memiliki pengetahuan di bidang yang luas tidak hanya dalam masalah agama namun juga harus memiliki pendidikan formal yang memadai disamping juga harus saling bisa bekerjasama dan mengerti hak masingmasing.

3. Mampu memilih pasangan yang tepat.

Memiliki akhlak dan pribadi yang baik di tunjang dengan penyeleksian pasangan hidup yang baik akan menghasilkan keturunan yang baik, secara teori genetika sifat dan gen yang dimiliki oleh kedua orang tua bahkan sampai kepada karakter mereka sedikit banyaknya akan diturunkan kepada anaknya. Pentingnya memilik pasangan yang memiliki pengetahuan agama yang kuat adalah demi memberikan pengetahuan agama yang sama kepada anak begitu pula ketika memilih seorang suami laki-laki yang dapat menempatkan diri sebagai pemimpin dalam keluarga dan mengerti akan hak-hak dalam rumah tangga serta taat pada ajaran Tuhannya, sehingga keluarga yang harmonis dapat tercapai.

4. Berjiwa pemimpin

Orang tua merupakan nahkoda bagi setiap rumah tangga terutama dibebankan pada kaum laki-laki atau bapak, karena secara kodrati laki-laki adalah pelindung bagi anak istrinya kelak maka mereka harus memiliki jiwa pemimpin dalam artian kelak akan menjadi panutan dalam menjalankan rumah tangganya serta memberi tuntunan kepada istri dan anaknya kelak, untuk itu menjadi seorang pemimpin haruslah berjiwa besar, berpengetahuan luas dan memahami dasar-dasar keagamaan.

Jurnal Darussalam; Jurnal Pendidikan, Komunikasi dan Pemikiran Hukum Islam Vol. XI, No 2:449-463. April 2020. ISSN: 1978-4767 (Cetak), ISSN: 2549-4171(Online) Terakreditasi Nasional. SK. No.36/E/KPT/2019 
5. Memiliki rasa cinta, kasih sayang, dan perhatian

Hasil penelitian Cumminghams dkk (2002) menyebutkan bahwa meningkatkan kepuasan perkawinan dapat menghasilkan pengasuhan yang baik, hubungan perkawinan, pengasuhan dan perilaku anak saling mempengaruhi, baik secara langsung maupun tidak langsung. Perkembangan kepribadian seorang anak diawali dari interaksi anak tersebut di dalam keluarganya. Penerimaan positif, kasih sayang yang tulus serta pola asuh yang baik akan membentuk karakter seorang anak ketika anak tersebut telah dewasa. Seorang anak yang dibesarkan dengan penuh kenyamanan dan kasih sayang di dalam keluarga niscaya akan menjadikan keluarga tempat untuk berbagi keluh kesah, begitu juga sebaliknya, jika seorang anak tidak mendapatkan kenyamanan di dalam keluarga maka akan mencari pelampiasan di luar rumah yang mengakibatkan seorang anak bingung akan identitas dirinya sendiri (Qurrotu Ayun, 2016:101)

Seorang calon orang tua bahkan sampai menjadi orang tua harus memiliki rasa cinta, kasih sayang dan memberikan perhatian penuh kepada perkembangan anak mereka, dan selalu memandang segala sesuatu tidak bersadarkan sudut pandangnya sendiri namun juga harus melihat dan menilai dari sudut pandang seorang anak. Ketika rasa tersebut telah tertanam dalam diri orang tua maka akan menimbulkan situasi yang nyaman dalam keluarga saling jujur dan terbuka antara satu sama lain juga akan tercipta karena tanpa rasa sayang dan cinta serta perhatian yang tulus kejujuran antara satu sama lain tidak akan bisa terwujud, dan ketika kejujuran tidak dapat terbina dalam keluarga maka akan berpengaruh terhadap tumbuh kembang anak terutama dalam masa remaja.

Menurut Muhammad Abdullah As-Suhaim (Arhjayati, 2013):

1. Jika anak kehilangan rasa percaya terhadap ucapan orang tua, kehilangan kejujuran kedua orang tua, lalu orang tua ingin menjauhkan anaknya dari kebiasaan menggunjing keburukan orang lain dan menjelaskan bahaya hal itu pada akidah, agama, dan akhlaknya, maka anak tidak akan mau menerima pengarahan dan tidak mau mendengarkan nasihat. Sebab, anak 
akan mengira bahwa ucapan orang tua itu seperti yang terdahulu, tidak jujur dan tidak perlu dipercaya

2. Jika kehilangan rasa percaya kepada orang tua, maka anak akan mencari orang lain yang lebih ia percaya, baik itu temannya ataupun gurunya. Jika guru dan teman yang dipercayainya itu saleh, maka anak tidak perlu dikhawatirkan. Akan tetapi, jika ternyata gurunya dan temannya lemah dan akhlaknya tercela maka masalah yang dihadapi anak akan menjadi semakin parah.

3. Jika tidak menemukan orang yang bisa mendengarkan keluh kesahnya lalu ia akan sibuk dengan kesedihan dan penderitaannya tanpa mengetahui siapa yang akan mengeluarkannya dari masalah itu maka anak akan memilih negosiasi diri. Dengan begitu ia tidak mampu menghadapi kehidupan nyata .

Kriteria yang telah dipaparkan sebelumnya merupakan garis besar dan kisikisi menuju kepada pembentukan kepribadian untuk menjadi orang tua yang baik yang kelak akan memberikan pendidikan kepada anaknya, dan yang perlu sedikit dibahas adalah para orang tua juga harus mengerti dan mengetahui konsep dan metode pembelajaran yang ditinjau dari konsep Islam diantaranya tilâwah, ta 'lîm', tarbiyah, ta 'dîb, tazkiyah dan tadlrîb (Arhjayati, 2013):

1. Tilâwah memandang konsep pendidikan harus dimulai dari pengetahuan dan minat membaca karena membaca adalah kunci yang dapat membawa kita ke dunia pengetahuan dan informasi, semakin banyak kita membaca maka akan semakin luas wawasan.

2. Ta'lîm'menitik beratkan konsep pendidikan kearah kecerdasan intelektual yakni kemampuan dalam menangkap pengetahuan formal serata kemampuan menganalisa situasi dan berkreasi.

3. Tarbiyah lebih mengarah pada insting tentang naluri cinta, kasih sayang dan saling membantu antara sesama manusia, hal ini mendorong kepedulian sosial seperti kepada alam, lingkungan dan sesama manusia.

4. Ta'dîb dan Tazkiyah memfokuskan kepada pengasahan kemampuan emosional dan spirituan keseimbangan keduanya merupakan kunci kesehatan rohani yang sifatnya kasat mata sehingga memerlukan perhatian 
lebih. Tadlrîb bertolak pada perkembangan fisik dan keterampilannya hal ini dapat dilihat dengan jelas karena bersifat fisik dan perkembangan jasmani seorang anak.

\section{F. Kesimpulan}

Dari tulisan diatas pendidikan karakter bukan sekedar mengajarkan mana yang benar dan mana yang salah, lebih dari itu, pendidikan karakter menanamkan kebiasaan (habituation) tentang hal mana yang baik sehingga anak-anak menjadi paham (kognitif) tentang mana yang benar dan salah, mampu merasakan (afektif) nilai yang baik dan biasa melakukannya (psikomotor). Dengan kata lain, pendidikan karakter yang baik harus melibatkan bukan saja aspek "pengetahuan yang baik" (moral knowing), akan tetapi juga "merasakan dengan baik" (moral feeling), dan "perilaku yang baik" (moral action). Pendidikan karakter menekankan pada habit atau kebiasaan yang terus-menerus dipraktekkan dan dilakukan. Pendidikan karakter berfungsi mengembangkan potensi dasar agar berhati baik, berpikiran baik, dan berperilaku baik, memperkuat dan membangun perilaku anak yang multikultur, meningkatkan peradaban siswa yang kompetitif dalam pergaulan di masyarakat.

\section{Daftar Pustaka}

Ali, Muhammad. 2008. Kamus Lengkap Bahasa Indonesia Modern. Jakarta: Pustaka Amani.

Anas Salahudin Dan Irwanto Alkrienciehie. 2013. Pendidikan Karakter (Pendidikan Berbasis Agama Dan Budaya Bangsa). Bandung: Pustaka Setia.

Ayun, Qurrotu. 2016. Pendidikan Dan Pengasuhan Keluarga Dalam Membentuk Perkembangan Kepribadian Anak: Perspektif Psikologi Perkembangan Islam Volume 26

Depdikbud. 1997. Kamus Besar Bahasa Indonesia. Jakarta. Edisi Kedua PN. Jakarta: Balai Pustaka

El Mubarok, Zaim. 2008. Membumikan Pendidikan Nilai. Bandung: Alfabeta.

Hariyadi, Laurensius Arliman, 2018. Peran Orangtua Dalam Mengawasi Anak Dalam Mengakses Media Internet Untuk Mewujudkan Perlindungan Hak Anak Soumatera. Law Review Volume 1 Nomor 2

Hasanah, Uswatun. 2016. Pola Asuh Orangtua Dalam Membentuk Karakter Anak, Jurnal Elementary Volume 2 nomer 2, Juli 
Mulyono, Abdurrahman. 2003. Pendidikan Bagi Anak Berkesulitan Belajar. Jakarta: Rineka Cipta.

Nursalam \& Muhammad Nawir. 2018. Pengaruh Tingkat Pendidikan Orang Tua Terhadap Pembentukan Kepribadian Anak Prosiding Seminar Nasional Pendidikan Era Revolusi"Membangun Sinergitas Dalam Penguatan Pendidikan Karakter Pada Era Ir 4.0". Universitas Muhammadiyah Jakarta, Indonesia. 24 Maret

Permono, Hendarti. 2013. Peran Orang Tua Dalam Dalam Optimalisasi Tumbuh Kembang Anak Untuk Membangun Karakter Anak Usia Dini, (Prosiding Seminar Nasional Parenting

Pinkan Regina Suva*, Achmad Zakky Mubarok, Muhamad Rivai, Mutiara Rizka Maulina, Fitri Eka Muslimah, Dwi Khalimas Segar, Muhammad Hasmi Rizal Fahlefi, Utaba Arzaqul Husna, Arifah Rohmaida Zulfa, Muchamad Ridwan. Urgensi Pembentukan Karakter Anak Di Era Globalisasi Melalui Penguatan Keluarga. Prosiding Konferensi Pengabdian Masyarakat Volume 1, Maret

Rahim, Arhjayati. 2013. Peranan Orang Tua Terhadap Pendidikan Karakter Remaja Putri Menurut Islam, Jurnal Al-Ulum, Volume. 13 Nomor 1, Juni

Sadulloh, Uyoh, Dkk. 2001. Pedagogik. Bandung: Alfabeta Cv.

Siti Anisah, Ani. 2011. Pola Asuh Orang Tua Dan Implikasinya Terhadap Pembentukan Karakter Anak. Jurnal Pendidikan Universitas Garut Fakultas Pendidikan Islam Dan Keguruan Jurnal Pendidikan Universitas Garut Vol. 05; No. 01

Zulaiha, Siti. 2018. Peran Orang Tua Dalam Membentuk Kepribadian Anak Di Rumah Pada Murid Sdn 06 Pal 100 Bermani Ulu Raya Kab. Rejang Lebong, Jurnal Pendidikan Dan Pembelajaran Dasar, Volume 5 Nomor (1 Juni

Jurnal Darussalam; Jurnal Pendidikan, Komunikasi dan Pemikiran Hukum Islam Vol. XI, No 2:449-463. April 2020. ISSN: 1978-4767 (Cetak), ISSN: 2549-4171(Online) Terakreditasi Nasional. SK. No.36/E/KPT/2019 